\title{
Concurrent and reactivation of hepatitis $B$ virus infection in diffuse large B-cell lymphoma: risk factors and survival outcome
}

\author{
Ya-fei Guo, Jing-xin Pan and Wei-huang Zhuang ${ }^{*}$
}

\begin{abstract}
Objective: To determine the clinical features and survival difference of HBV related and Non-HBV related diffuse large B-cell lymphoma (DLBCL) and to evaluate the occurrence of HBV reactivation in DLBCL patients and related risk factors for HBV reactivation after R-CHOP therapy.

Methods: A total of 246 patients diagnosed with CD20+ DLBCL were enrolled from June 2010 to June 2015. The medical records and survival data were analysed. Multivariate logistic regression analysis was used to identify predictors of HBV reactivation. Survival curves were performed by the Kaplan-Meier method.

Results: Among patients enrolled, 80 patients were HBsAg sero-positive and 166 patients were HBsAg seronegative. Findings showed that HBsAg sero-negative patients were significantly older than that of patients with HBsAg sero-positive $(P<0.001)$. Proportion of $B$ symptom positive patients in HBsAg sero-positive were higher $(p=$ 0.002). Higher LDH level $(P=0.019)$ and late Ann Arbor stage $(P=0.010)$ were more often observed in patients with $\mathrm{HBsAg}$ sero-positive. The rate of complete response, partial response, stable disease and progress disease in $\mathrm{HBs} A g$ sero-negative group were 63.9, 16.9, 1.1 and $18.1 \%$, respective, which is significantly higher than that in HBsAg seropositive group (36.2, 18.8, 1.2 and 43.8\%). Kaplan-Meier analysis showed that DLBCL patients with HBsAg seronegative had better prognosis. In total, 17 patients showed HBV reactivation among 166 patients (10.2\%) with HBsAg sero-negative after R-CHOP treatment, while a significant higher HBV reactivation $18.75 \%(9 / 48)$ in HBsAb negative group were observed, with 8.25\% (8/97) patients in HBsAb level 10-100 U/mL group, and 0\% patients in $\mathrm{HBsAb}$ level higher than $100 \mathrm{U} / \mathrm{mL}$ group. Multivariable analysis showed that serum HBsAb and serum HBcAb were independent risk factors for HBV reactivation in DLBCL patients.

Conclusion: Our data revealed that characteristics and prognosis were significantly different between HBV related DLBCL than non-HBV related DLBCL patients. DLBCL patients with resolved hepatitis $B$ are at a higher risk of developing HBV reactivation after R-CHOP chemotherapy compared with $\mathrm{HBsAg}$-negative/HBcAb negative patients.
\end{abstract}

Keywords: Hepatitis B virus, Diffuse large B-cell lymphoma, Rituximab, HBV reactivation, Risk factors

\footnotetext{
* Correspondence: 13808521170@163.com

Department of Hematology, The Second Affiliated Hospital of Fujian Medical University, Quanzhou 362000, China
}

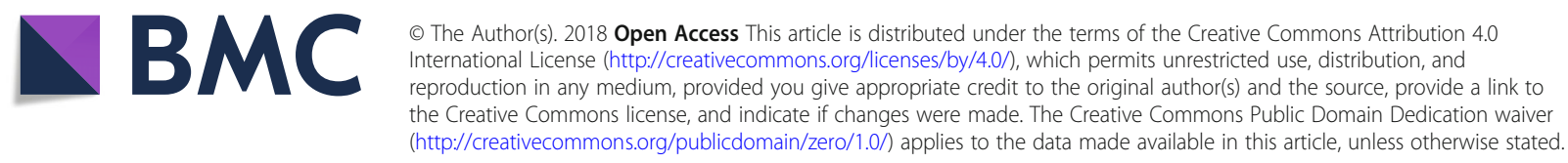




\section{Introduction}

Hepatitis B virus (HBV) infection remains a heavy health burden worldwide, especially in middle-low incomes countries. Chronic hepatitis B (CHB) affects an estimated 400 million people and increased risk of developing adverse outcomes, including cirrhosis, hepatic decompensation, and hepatocellular carcinoma [1]. In the natural history of $\mathrm{HBV}$ infection, the role of hepatitis $\mathrm{D}$ virus (HDV) cannot be ignored [2, 3]. HDV is a defective RNA virus. $\mathrm{HDV}$ infection to hepatocyte is dependent on $\mathrm{HBV}$ infection [3]. Previous studies reported that chronic infection with HDV exacerbates the poor prognosis of HBV infection [4]. Patients with co-infection with HDV and HBV have an increased risk of cirrhosis and liver cancer [4, 5]. HBV chronic infection is also associated with some extrahepatic disease $[6,7]$. Previous studies have confirmed that the association between HBV infection and non-Hodgkin's lymphoma (NHL) [8-11]. With regard to the NHL subtypes, a firm association was found with B-cell NHL, especially with diffuse large B-cell lymphoma (DLBCL), the most common subtype of B-cell NHL [12, 13]. In HBV prevalent countries, the patients with $\mathrm{HBV}$ was more likely to suffer from DLBCL [7].

Rituximab is a chimeric anti-CD20 monoclonal antibody licensed for DLBCL treatment. Rituximab in combination with cyclophosphamide, doxorubicin, vincristine, and prednisone (R-CHOP) is the current standard chemotherapy for diffuse large B-cell lymphoma (DLBCL) [14, 15]. Recent evidences have shown that HBV reactivation was associated with the use of rituximab [16, 17]. Without prophylaxis, hepatitis $\mathrm{B}$ core antibody ( $\mathrm{HBcAb})$-positive patients receiving rituximab therapy showed a high incidence of HBV reactivation [18-20]. Prophylaxis antiviral is recommended for these patients $[18,19]$. However, the data on the difference of HBV related DLBCL and Non-HBV related DLBCL, and the incidence of HBV reactivation with its risk factors in DLBCL patients after R-CHOP anticaner therapy are still limited.

This retrospective study, therefore, was aim 1) to determine the difference of characteristics and prognosis between HBV related and Non-HBV related DLBCL, 2) to evaluate the occurrence of HBV reactivation in DLBCL patients, and 3) to identify risk factors for HBV reactivation in patients with DLBCL after R-CHOP anticancer therapy.

\section{Subjects and methods \\ Subjects}

All patients who were diagnosed with CD20+ DLBCL and treated with R-CHOP anticancer therapy were enrolled in this study from June. 2010 and June. 2015. The HBsAg status was determined before anticancer therapy. All patients underwent HBV serology tests, including those for HBsAb, hepatitis B e antigen (HBeAg), hepatitis B e antibody (HBeAb), and HBcAb. HBV serology, HBV DNA, and liver function (alanine aminotransferase [ALT], aspartate aminotransferase [AST], and total bilirubin [TB] levels) were examed before each chemotherapy cycle and at least every 3 months during the follow-up period. Patients were excluded if there is evidences of hepatitis A virus (HAV), hepatitis $\mathrm{C}$ virus ( $\mathrm{HCV})$, hepatitis $\mathrm{D}$ virus, hepatitis $\mathrm{E}$ virus, or human immunodeficiency virus infection, coexistence of another type of lymphoma, associated chronic inflammation, and a previous malignancy.

HBV serological markers were determined using a commercially available radioimmunoassay (ARCHITECT i2000SR, Abbott Laboratories, 100 Abbott Park Road, Illinois, US). Serum HBV DNA levels were measured by real-time polymerase chain reaction with a linear range of $1000 \mathrm{IU} / \mathrm{mL}$ to $1 \times 10^{8} \mathrm{IU} / \mathrm{mL}$ according to the manufacturer's instructions (Daan Gene Co, Ltd. of Sun Yat-sen University, Guangdong, China) [21].

This study was approved by the Institutional Review Board of The Second Affiliated Hospital of Fujian Medical University. Informed consents for the collection of medical information were obtained from all patients at their first visit. All pathologic specimens were reviewed and reclassified according to World Health Organization (WHO) criteria.

\section{Definitions in study}

The international prognosis index (IPI) included five factors: age ( $\leq 60$ years vs. $>60$ years), lactate dehydrogenase $(\mathrm{LDH})$ value $(\leq 245 \mathrm{U} / \mathrm{mL}$ vs. $>245 \mathrm{U} / \mathrm{mL})$, Eastern Cooperative Oncology Group (ECOG) performance status (PS) (0-1 vs. > 1), Ann Arbor stage (I/II vs. III/IV), and the number of extranodal involvements $(0-1$ vs. $>1)$. IPI scores were separated based on the number of factors present.

\section{Statistical analysis}

Overall survival (OS) was measured from the date of diagnosis to the date of death from any cause or to the date of the last follow-up visit. The associations of HBV reactivation and characteristics of patients were examined by univariate analysis, chi square or Fisher's exact test. Multivariate logistic regression analysis was performed to identify predictors of HBV reactivation. Survival curves were drawn by the Kaplan-Meier methodusing the log-rank test. Statistical significance was defined as $P$ $<0.05$ (two-tailed). Statistical analysis was performed with SPSS version 13.0 software (Chicago, USA).

\section{Results}

Patients characteristics according to HBsAg status

A total of 246 patients with DLBCL were enrolled in the study (Fig. 1). Among them, 80 patients were confirmed having $\mathrm{HBsAg}$ sero-positive and 166 patients were $\mathrm{HBsAg}$ sero-negative. The results showed that HBsAg sero-negative patients were significantly older than others $(P<0.001)$. 
Patients with HBsAg sero-positive were more likely to have B symptoms $(p=0.002)$. Higher LDH level $(P=0.019)$ and late Ann Arbor stage $(P=0.010)$ were more often observed in patients with HBsAg sero-positive (Table 1).

\section{Response to chemotherapy}

To determine the difference of response rate to chemotherapy between two group, the responses rate was calculated and compared (Table 2). The rate of complete response, partial response, stable disease and progress disease of DLBCL in $\mathrm{HBsAg}$ sero-negative group were $63.9,16.9,1.1$ and $18.1 \%$, respective, which was significantly higher than that in HBsAg sero-positive group with the rate of complete response, partial response, stable disease and progress disease being 36.2, 18.8, 1.2 and 43.8\%.

Kaplan-Meier analysis showed the overall survival between HBsAg sero-positive patients and HBsAg sero-negative was significantly different $(P=0.003)$. As shown in Fig. 2, patients of DLBCL with HBsAg sero-negative have better prognosis.

Table 1 Patients characteristics according to HBsAg status

\begin{tabular}{|c|c|c|c|}
\hline \multirow[t]{2}{*}{ Variable } & \multicolumn{2}{|c|}{ Diffuse large B-cell lymphoma } & \multirow[t]{2}{*}{$P$ value } \\
\hline & HBsAg-positive & HBsAg-negative & \\
\hline Sample size & 80 & 166 & \\
\hline Age, years & & & $<0.001$ \\
\hline$\leq 60$ & $68(85.0 \%)$ & $105(63.3 \%)$ & \\
\hline$>60$ & $12(15.0 \%)$ & $61(36.7 \%)$ & \\
\hline Gender & & & 0.219 \\
\hline Male & $50(62.5 \%)$ & $90(54.2 \%)$ & \\
\hline Female & $30(37.5 \%)$ & $76(45.8 \%)$ & \\
\hline B symptom & & & 0.002 \\
\hline Positive & $46(57.5 \%)$ & $60(36.1 \%)$ & \\
\hline Negative & $34(42.5 \%)$ & $106(63.9 \%)$ & \\
\hline IPI score & & & 0.124 \\
\hline $1-2$ & $48(60.0 \%)$ & $116(69.9 \%)$ & \\
\hline $3-5$ & $32(40.0 \%)$ & $50(30.1 \%)$ & \\
\hline LDH & & & 0.019 \\
\hline Normal & $35(43.8 \%)$ & $99(59.6 \%)$ & \\
\hline Elevated & $45(56.2 \%)$ & $67(40.4 \%)$ & \\
\hline Extranodal sites & & & 0.128 \\
\hline$<2$ & $44(55.0 \%)$ & $108(65.1 \%)$ & \\
\hline$\geq 2$ & $36(45.0 \%)$ & $58(34.9 \%)$ & \\
\hline Ann Arbor stage & & & 0.010 \\
\hline$|-| \mid$ & $19(23.8 \%)$ & $67(40.4 \%)$ & \\
\hline III-IV & $61(76.3 \%)$ & 99 (59.6\%) & \\
\hline
\end{tabular}

Abbreviations: $H B s A g$ hepatitis B surface antigen, IPI international prognosis index, $L D H$ lactate dehydrogenase
Patients characteristics according to $\mathrm{HBV}$ reactivation

A total of 17 patients showed HBV reactivation among 166 patients with $\mathrm{HBsAg}$ sero-negative after R-CHOP treatment. The characteristics of patients were shown in Table 3. All patients experienced HBV reactivation were HBcAb positive before treatment $(P<0.001)$. The HBsAb positive rate were significantly lower in patients with HBV reactivation than the others $(P=0.021)$. The serum HBV DNA level in patients during reactivation was $4.38 \pm 2.25 \log _{10} \mathrm{IU} / \mathrm{mL}$.

To further confirm the relationship between $\mathrm{HBsAb}$ and HBV reactivation. The proportion of HBV reactivation according HBsAb level were calculated among the 166 patients with HBsAg sero-negative before treatment. A significantly different were observed with $18.75 \%$ (9/ 48) patients with $\mathrm{HBV}$ reactivation in $\mathrm{HBsAb}$ negative group, $8.25 \%$ (8/97) patients in HBsAb level 10-100 U/ $\mathrm{mL}$ group, and $0 \%$ patients in HBsAb level higher than $100 \mathrm{U} / \mathrm{mL}$ group. As shown in Fig. 3.

\section{Univariate and multivariate analyses of risk factors associated with $\mathrm{HBV}$ reactivation}

A univariate and multivariate analyses were conducted to analysis the risk factor associated with $\mathrm{HBV}$ reactivation. The univariate analyses indicated serum HBsAb and $\mathrm{HBcAb}$ were risk factors associated with $\mathrm{HBV}$ reactivation after R-CHOP chemotherapy. Similarly, multivariate analyses show that low HBsAb level $(\mathrm{OR}=0.917, P=0.044)$ and positive $\mathrm{HBcAb}$ level $(\mathrm{OR}=2.201, P<0.001)$ were independent risk factors associated with HBV reactivation in DLBCL patients receiving $\mathrm{R}-\mathrm{CHOP}$ chemotherapy (Table 4).

\section{Discussion}

This study demonstrated that the characteristics and prognosis were significantly different between $\mathrm{HBV}$ related DLBCL than non-HBV related DLBCL. For those DLBCL patients who were have both $\mathrm{HBsAg}$ sero-negative, they had a significantly higher risk of $\mathrm{HBV}$ reactivation compared with $\mathrm{HBsAg}$-negative/HBcAb-negative patients after rituximab containing chemotherapy. Baseline $\mathrm{HBcAb}$ positivity and $\mathrm{HBsAb}$ negativity were independent risk factors for HBV reactivation in patients with DLBCL.

Chronic HBV infection was considered to be associated with lymphomagenesis, especially for DLBCL [22]. Also, several studies have demonstrated that the incidence of HBV infection was higher in patients with B-cell lymphoma than in the general population [23, 24]. Furthermore, our study demonstrated that CD20+ DLBCL patients with resolved HBV infection were more likely to experience HBV reactivation, compared with $\mathrm{HBsAg-negative/HBcAb-nega-}$ tive patients using rituximab containing chemotherapy.

In this study, it stands to reason that DLBCL patients with HBsAg-negative/HBcAb-positive should monitor HBV serology, HBV DNA closely before each chemotherapy cycle. 


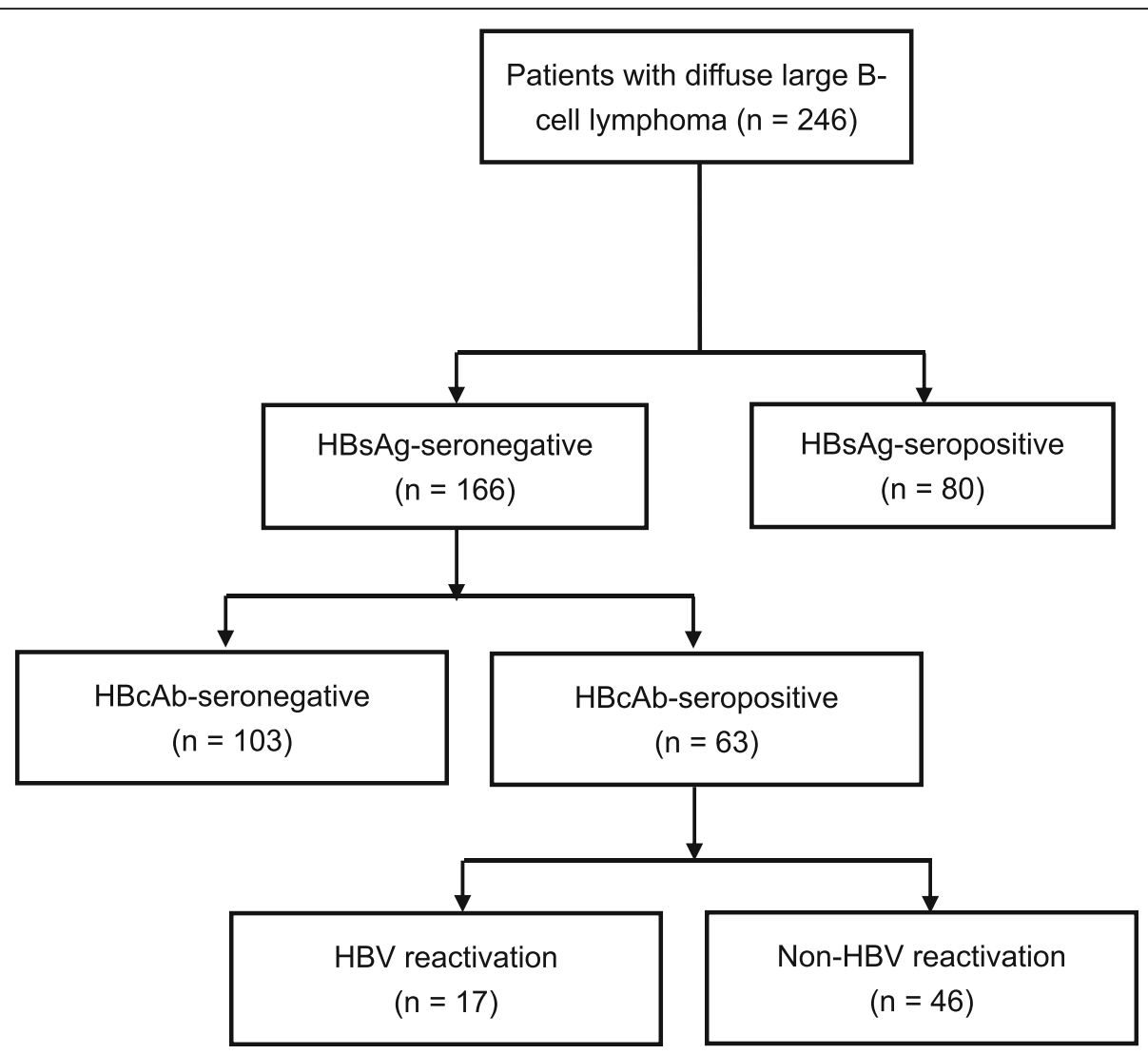

Fig. 1 Flow chart of the study. The flow chart of the study was shown

Furthermore, prophylactic antiviral treatments were thus recommended for $\mathrm{HBsAg}$-negative/HBcAb-positive patients. Consistently, study recommend prophylaxis with antiviral drugs in all $\mathrm{HBs} A g$-negative/ $\mathrm{HBCAb}$-positive patients who receive rituximab-containing regimens for hematologic malignancies because of a high risk of HBV reactivation [25]. Lamivudine is widely used for prophylaxis, while its efficacy is hampered by the development of viral mutations result in drug resistance [26-28]. Currently, the FDA approves antiviral drugs for inhibiting $\mathrm{HBV}$ replication, in addition to LAM, as well as telbivudine, adefovir, entecavir and tenofovir. Among them, LAM, telbivudine and adefovir are low-resistance barriers antiviral agents, while entecavir and

Table 2 Proportion of patients with Response to chemotherapy

\begin{tabular}{llll}
\hline \multirow{2}{*}{$\begin{array}{l}\text { Response to } \\
\text { chemotherapy }\end{array}$} & \multicolumn{2}{l}{ Diffuse large B-cell lymphoma } & $P$ value \\
\cline { 2 - 3 } & HBsAg-positive & HBsAg-negative & \\
\hline Sample size & 80 & 166 & $<0.001$ \\
Response & & & \\
Complete response & $29(36.2 \%)$ & $106(63.9 \%)$ & \\
Partial response & $15(18.8 \%)$ & $28(16.9 \%)$ & \\
Stable disease & $1(1.2 \%)$ & $2(1.1 \%)$ & \\
Progress disease & $35(43.8 \%)$ & $30(18.1 \%)$ & \\
\hline
\end{tabular}

tenofovir are antiviral drugs with potent anti-HBV effect and high-resistance barriers, so they are recommended as first-line drugs by various guidelines [29-31]. Maybe others antiviral agents such as entecavir and tenofovir would be more effective and associated with minimal resistance [32, 33], but it still need further study to confirm.

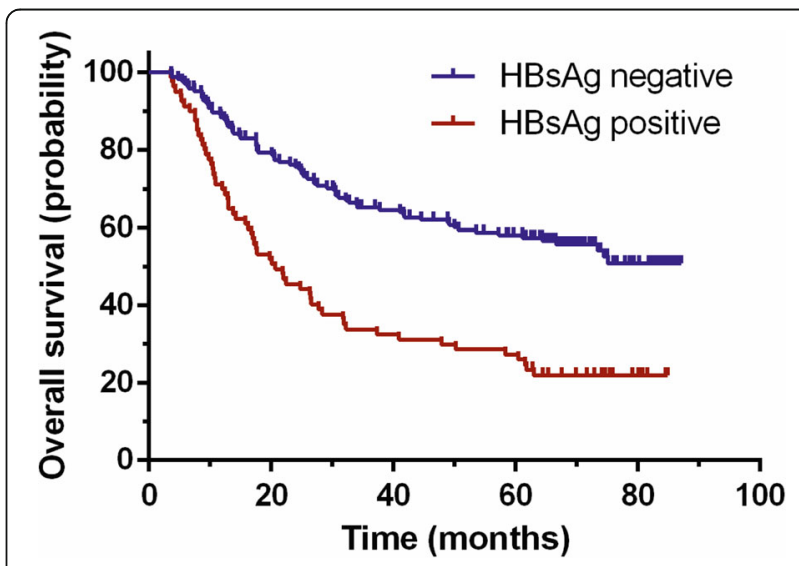

Fig. 2 Kaplan-Meier analysis of $D L B C L$ with or without HBV infection. Results showed the overall survival between HBsAg sero-positive patients and HBsAg sero-negative was significantly different $(P=0.003)$ 
Table 3 Patients characteristics according to HBV reactivation

\begin{tabular}{|c|c|c|c|}
\hline \multirow[t]{2}{*}{ Variable } & \multicolumn{2}{|c|}{ HBsAg (-) Diffuse large B-cell lymphoma } & \multirow[t]{2}{*}{$P$ value } \\
\hline & HBV reactivation & Non-HBV reactivation & \\
\hline Sample size & 17 & 149 & \\
\hline Age, years & & & 0.869 \\
\hline$\leq 60$ & $11(64.7 \%)$ & $94(63.1 \%)$ & \\
\hline$>60$ & $6(35.3 \%)$ & 55 (36.9\%) & \\
\hline Gender & & & 0.911 \\
\hline Male & $9(52.9 \%)$ & $81(54.3 \%)$ & \\
\hline Female & $8(47.1 \%)$ & $68(45.7 \%)$ & \\
\hline B symptom & & & 0.542 \\
\hline Positive & $5(29.4 \%)$ & 55 (36.9\%) & \\
\hline Negative & $12(70.6 \%)$ & $94(63.1 \%)$ & \\
\hline IPI score & & & 0.108 \\
\hline $1-2$ & $9(52.9 \%)$ & $107(71.8 \%)$ & \\
\hline $3-5$ & $8(47.1 \%)$ & $42(28.2 \%)$ & \\
\hline LDH & & & 0.264 \\
\hline Normal & $8(47.1 \%)$ & $91(61.1 \%)$ & \\
\hline Elevated & $9(52.9 \%)$ & $58(38.9 \%)$ & \\
\hline Extranodal sites & & & 0.128 \\
\hline$<2$ & $11(64.7 \%)$ & $97(65.1 \%)$ & \\
\hline$\geq 2$ & $6(35.3 \%)$ & 52 (34.9\%) & \\
\hline Ann Arbor stage & & & 0.135 \\
\hline$|-| \mid$ & $4(23.5 \%)$ & $63(42.3 \%)$ & \\
\hline III-IV & $13(76.5 \%)$ & 86 (57.7\%) & \\
\hline HBCAb status & & & $<0.001$ \\
\hline Positive & 17 (100\%) & 46 (30.9\%) & \\
\hline Negative & $0(0.0 \%)$ & $103(69.1 \%)$ & \\
\hline HBsAb status & & & 0.021 \\
\hline Positive & $8(47.1 \%)$ & $110(73.8 \%)$ & \\
\hline Negative & $9(52.9 \%)$ & 39 (26.2\%) & \\
\hline
\end{tabular}

Abbreviations: $H B s A b$ hepatitis B surface antibody, IPI international prognosis index, $L D H$ lactate dehydrogenase

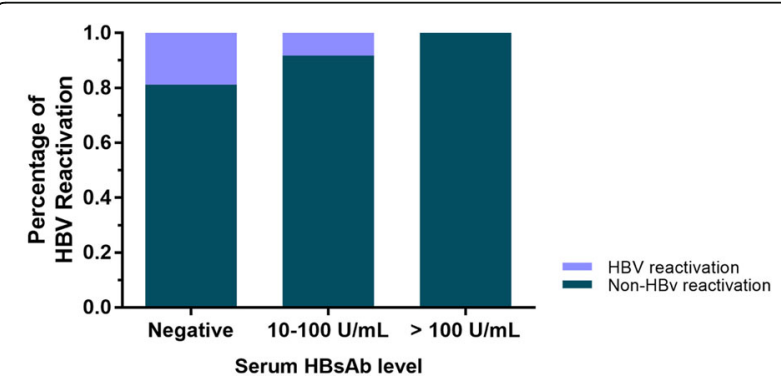

Fig. 3 The proportion of HBV reactivation according HBsAb level. A significantly different were observed with $18.75 \%$ (9/48) patients with HBV reactivation in HBsAb negative group, 8.25\% (8/97) patients in HBsAb level $10-100 \mathrm{U} / \mathrm{mL}$ group, and $0 \%$ patients in HBsAb level higher than $100 \mathrm{U} / \mathrm{mL}$ group
Table 4 Univariate and multivariate analyses for HBV reactivation

\begin{tabular}{|c|c|c|c|c|c|c|}
\hline \multirow[t]{2}{*}{ Variables } & \multicolumn{3}{|c|}{ Univariate analysis } & \multicolumn{3}{|c|}{ Multivariate analysis } \\
\hline & $\mathrm{HR}$ & $95 \% \mathrm{Cl}$ & $P$ & $\mathrm{HR}$ & $95 \% \mathrm{Cl}$ & $P$ \\
\hline Age, years & 0.871 & $0.749-1.113$ & 0.173 & & & \\
\hline Sex & 1.013 & $0.784-1.308$ & 0.921 & & & \\
\hline B symptom & 1.077 & $0.857-1.353$ & 0.526 & & & \\
\hline IPI score & 1.073 & $0.811-1.419$ & 0.621 & & & \\
\hline LDH & 0.978 & $0.802-1.192$ & 0.822 & & & \\
\hline $\begin{array}{l}\text { Extranodal } \\
\text { sites }\end{array}$ & 1.089 & $0.884-1.341$ & 0.424 & & & \\
\hline $\begin{array}{l}\text { Ann Arbor } \\
\text { stage }\end{array}$ & 0.992 & $0.763-1.289$ & 0.951 & & & \\
\hline $\mathrm{HBsAb}$ & 0.818 & $0.570-0.897$ & 0.037 & 0.917 & $0.705-0.994$ & 0.044 \\
\hline $\mathrm{HBcAb}$ & 2.265 & $1.085-3.474$ & $<0.001$ & 2.201 & $1.028-2.703$ & $<0.001$ \\
\hline
\end{tabular}

Abbreviations: $H B s A b$ hepatitis B surface antibody, IPI international prognosis index, $L D H$ lactate dehydrogenase. $H B C A b$ hepatitis $B$ core antibody

Our study had several key points. We compared the characteristics and prognosis between $\mathrm{HBV}$ related DLBCL than non-HBV related DLBCL. We also compared the incidence of $\mathrm{HBV}$ reactivation between $\mathrm{HBcAb}$-positive and HBcAb-negative patients and identified risk factors for the occurrence of $\mathrm{HBV}$ reactivation. China is a high endemic HBV burden area [34-36], and this is the first study to confirm these findings However, this study was limited by its retrospective nature. Another limitation was that all the patients were come from a single institute. Prospective studies including more patients from more centres are required to confirm our findings and to determine the most effective monitoring and therapeutic strategies.

In conclusion, this study demonstrated that the characteristics and prognosis were different between HBV related DLBCL than non-HBV related DLBCL patients. DLBCL patients with resolved hepatitis $B$ were at a higher risk of developing $\mathrm{HBV}$ reactivation after rituximab containing chemotherapy compared with HBsAg-negative/ $\mathrm{HBcAb}$ negative patients. Close monitoring of HBV DNA levels and liver function and prompt antiviral therapy are required in these patients. More large-scale studies are required to identify host and viral factor that can help to predict the occurrence of HBV reactivation and thus allow the design of individualized strategies for preventing HBV-related hepatitis.

Acknowledgements

Authors would like to thank help and support from hospital for the study.

\section{Funding}

Not applicable.

\section{Availability of data and materials}

Authors can confirm all relevant data are included in the article and materials are available on request from the authors. 


\section{Authors' contributions}

WHZ designed the study and edited the final version of the manuscript; YFG conducted the sample analysis and drafted the paper; YFG and JXP contributed to the statistical analyses; JXP and WHZ provided the clinical samples. All authors read and approved the final manuscript.

\section{Ethics approval and consent to participate}

The study was reviewed and approved by the Medical Ethics Committee of The Second Affiliated Hospital of Fujian Medical University. All study participants, or their legal guardian, provided informed written consent prior to study enrollment.

\section{Consent for publication}

Not applicable.

\section{Competing interests}

The authors declare that they have no competing interests.

\section{Publisher's Note}

Springer Nature remains neutral with regard to jurisdictional claims in published maps and institutional affiliations.

\section{Received: 14 August 2018 Accepted: 30 November 2018} Published online: 12 December 2018

\section{References}

1. Sarin SK, Kumar M, Lau GK, Abbas Z, Chan HL, Chen CJ, Chen DS, Chen HL, Chen PJ, Chien RN, et al. Asian-Pacific clinical practice guidelines on the management of hepatitis B: a 2015 update. Hepatol Int. 2016;10(1):1-98

2. Stroffolini T, Sagnelli E, Rapicetta M, Felaco FM, Filippini P, Annella T, Petruzziello A, Chionne P, Sarrecchia B, Piccinino F, et al. Hepatitis B virus DNA in chronic HBsAg carriers: correlation with HBeAg/anti-HBe status, antiHD and liver histology. Hepatogastroenterology. 1992;39(1):62-5.

3. Sagnelli E, Felaco FM, Rapicetta M, Stroffolini T, Petruzziello A, Annella T, Chionne P, Pasquale G, Filippini P, Peinetti $P$, et al. Interaction between HDV and HBV infection in HBsAg-chronic carriers. INFECTION. 1991;19(3):155-8.

4. Romeo R, Petruzziello A, Pecheur El, Facchetti F, Perbellini R, Galmozzi E, Khan NU, Di Capua L, Sabatino R, Botti G, et al. Hepatitis delta virus and hepatocellular carcinoma: an update. Epidemiol Infect. 2018;146(13):1612-8.

5. Petruzziello A. Epidemiology of hepatitis B virus (HBV) and hepatitis C virus (HCV) related hepatocellular carcinoma. Open Virol J. 2018;12:26-32.

6. Joshi SS, Coffin CS. Hepatitis B virus lymphotropism: emerging details and challenges. Biotechnol Genet Eng Rev. 2018;34(1):139-51.

7. Kamiza AB, Su FH, Wang WC, Sung FC, Chang SN, Yeh CC. Chronic hepatitis infection is associated with extrahepatic cancer development: a nationwide population-based study in Taiwan. BMC Cancer. 2016;16(1):861.

8. Bassig BA, Willhauck-Fleckenstein M, Shu XO, Koh WP, Gao YT, Purdue MP, Xiang YB, Adams-Haduch J, Wang R, Brenner N, et al. Serologic markers of viral infection and risk of non-Hodgkin lymphoma: a pooled study of three prospective cohorts in China and Singapore. Int J Cancer. 2018;143(3):570-9.

9. Ren W, Ye X, Su H, Li W, Liu D, Pirmoradian M, Wang X, Zhang B, Zhang Q, Chen $L$, et al. Genetic landscape of hepatitis B virus-associated diffuse large B-cell lymphoma. BLOOD. 2018;131(24):2670-81.

10. Yan X, Zhou M, Lou Z, Mu Q, Sheng L, Zhang P, Wang Y, Ouyang G. Diffuse large B-cell lymphoma with concurrent hepatitis B virus infection in the MabThera era: unique clinical features and worse outcomes. J Cancer Res Ther. 2018;14(Supplement):S248-53.

11. Yang HC, Tsou HH, Pei SN, Chang CS, Chen JH, Yao M, Lin SJ, Lin J, Yuan O Xia N, et al. Quantification of HBV core antibodies may help predict HBV reactivation in patients with lymphoma and resolved $\mathrm{HBV}$ infection. J Hepatol. 2018;69(2):286-92.

12. Huang CE, Yang YH, Chen YY, Chang JJ, Chen KJ, Lu CH, Lee KD, Chen PC, Chen CC. The impact of hepatitis B virus infection and vaccination on the development of non-Hodgkin lymphoma. J Viral Hepat. 2017;24(10):885-94.

13. Tang $Z$, Li X, Wu S, Liu Y, Qiao Y, Xu D, Li J. Risk of hepatitis B reactivation in $\mathrm{HBsAg}$-negative/HBCAb-positive patients with undetectable serum HBV DNA after treatment with rituximab for lymphoma: a meta-analysis. Hepatol Int. 2017;11(5):429-33.

14. Freeman $\mathrm{CL}$, Sehn $\mathrm{LH}$. A tale of two antibodies: obinutuzumab versus rituximab. Br J Haematol. 2018;182(1):29-45.
15. Salles G, Barrett M, Foa R, Maurer J, O'Brien S, Valente N, Wenger M, Maloney DG. Rituximab in B-cell hematologic malignancies: a review of 20 years of clinical experience. Adv Ther. 2017;34(10):2232-73.

16. Nakaya A, Fujita S, Satake A, Nakanishi T, Azuma Y, Tsubokura Y, Hotta M, Yoshimura H, Ishii K, Ito T, et al. Delayed HBV reactivation in rituximabcontaining chemotherapy: how long should we continue anti-virus prophylaxis or monitoring HBV-DNA? Leuk Res. 2016;50:46-9.

17. Tanaka Y. Risk management of HBV reactivation: construction of check system. Rinsho Byori. 2015;63(9):1052-9.

18. Koutsianas C, Thomas K, Vassilopoulos D. Prevention of HBV reactivation in patients treated with biologic agents. Expert Rev Clin Pharmacol. 2016:1-11.

19. Kusumoto S, Tanaka Y, Suzuki R, Watanabe T, Nakata M, Takasaki H, Fukushima N, Fukushima T, Moriuchi Y, Itoh K, et al. Monitoring of hepatitis $B$ virus (HBV) DNA and risk of $\mathrm{HBV}$ reactivation in B-cell lymphoma: a prospective observational study. Clin Infect Dis. 2015:61(5):719-29.

20. Liu WP, Zheng W, Song YQ, Ping LY, Wang GQ, Zhu J. Hepatitis B surface antigen seroconversion after HBV reactivation in non-Hodgkin's lymphoma. World J Gastroenterol. 2014;20(17):5165-70.

21. Cai SH, Lv FF, Zhang YH, Jiang YG, Peng J. Dynamic comparison between Daan real-time PCR and Cobas TaqMan for quantification of HBV DNA levels in patients with CHB. BMC Infect Dis. 2014;14:85

22. Merli M, Rattotti S, Gotti M, Arcaini L. Antiviral therapies for managing viral hepatitis in lymphoma patients. Expert Opin Pharmacother. 2017;18(4):363-76.

23. Dong HJ, Ni LN, Sheng GF, Song HL, Xu JZ, Ling Y. Risk of hepatitis B virus (HBV) reactivation in non-Hodgkin lymphoma patients receiving rituximabchemotherapy: a meta-analysis. J Clin Virol. 2013;57(3):209-14.

24. Nath A, Agarwal R, Malhotra P, Varma S. Prevalence of hepatitis B virus infection in non-Hodgkin lymphoma: a systematic review and meta-analysis. Intern Med J. 2010;40(9):633-41.

25. Pei $\mathrm{SN}$, Chen $\mathrm{CH}$. Risk and prophylaxis strategy of hepatitis B virus reactivation in patients with lymphoma undergoing chemotherapy with or without rituximab. Leuk Lymphoma. 2015;56(6):1611-8.

26. Cai S, Cao J, Yu T, Xia M, Peng J. Effectiveness of entecavir or telbivudine therapy in patients with chronic hepatitis $B$ virus infection pre-treated with interferon compared with de novo therapy with entecavir and telbivudine. Medicine (Baltimore). 2017;96(22):e7021

27. Cai S, Li Z, YU T, Xia M, Peng J. Serum hepatitis B core antibody levels predict HBeAg seroconversion in chronic hepatitis B patients with high viral load treated with nucleos(t)ide analogs. INFECT DRUG RESIST. 2018;11:469-77.

28. Cai S, Yu T, Jiang Y, Zhang Y, LV F, Peng J. Comparison of entecavir monotherapy and de novo lamivudine and adefovir combination therapy in HBeAg-positive chronic hepatitis B with high viral load: 48-week result. Clin Exp Med. 2016;16(3):429-36.

29. Ou H, Cai S, Liu Y, Xia M, Peng J. A noninvasive diagnostic model to assess nonalcoholic hepatic steatosis in patients with chronic hepatitis B. Therap Adv Gastroenterol. 2017:10(2):207-17.

30. Xue X, Cai S. Comment on "assessment of liver stiffness in pediatric Fontan patients using transient Elastography". Can J Gastroenterol Hepatol. 2016; 2016:9343960

31. Terrault NA, Bzowej NH, Chang KM, Hwang JP, Jonas MM, Murad MH. AASLD guidelines for treatment of chronic hepatitis B. HEPATOLOGY. 2016;63(1):261-83.

32. Wu X, Cai S, Li Z, Zheng C, Xue X, Zeng J, Peng J. Potential effects of telbivudine and entecavir on renal function: a systematic review and metaanalysis. Virol J. 2016;13:64

33. Zeng J, Cai S, Liu J, Xue X, Wu X, Zheng C. Dynamic changes in liver stiffness measured by transient Elastography predict clinical outcomes among patients with chronic hepatitis B. J Ultrasound Med. 2017:36(2):261-8.

34. Cai SH, Lu SX, Liu LL, Zhang CZ, Yun JP. Increased expression of hepatocyte nuclear factor 4 alpha transcribed by promoter 2 indicates a poor prognosis in hepatocellular carcinoma. Therap Adv Gastroenterol. 2017;10(10):761-71.

35. Cai S, Ou Z, Liu D, Liu L, Liu Y, Wu X, Yu T, Peng J. Risk factors associated with liver steatosis and fibrosis in chronic hepatitis $B$ patient with component of metabolic syndrome. United European Gastroenterol J. 2018;6(4):558-66.

36. Xue X, Cai S, Ou H, Zheng C, Wu X. Health-related quality of life in patients with chronic hepatitis $B$ during antiviral treatment and off-treatment. Patient Prefer Adherence. 2017;11:85-93. 